\title{
Digestibility and ruminal digestion kinetics of corn silage
}

[Digestibilidade e cinética da digestão no rúmen de silagem de milho]

\author{
O.N. Di Marco, M.S. Aello, S. Arias \\ Universidad Nacional de Mar del Plata \\ Facultad de Ciencias Agrarias - EEA INTA Balcarce \\ CC 276 (7620) Balcarce, BA, Argentina
}

\begin{abstract}
The in situ dry matter (DM) disappearance of corn silages in two maturity stages (milk grain and half milk line) of known in vivo and in vitro digestibility was determined, with the main purpose of comparing digestibility values with the ruminal disappearance at 24 and $48 \mathrm{~h}$ of incubation. A secondary goal was the description of their ruminal digestion kinetics, from which the effective degradability was calculated at an assumed passage rate of $4 \% / \mathrm{h}$. Data of in vivo, in vitro and in situ degradability at 24 and 48 -h were analyzed with a linear model that included as fixed effects the maturity and the methodology of evaluation, and the kinetic data were described by the exponential model of McDonald. There was a significant effect $(\mathrm{P}<0.05)$ of methodology in the estimation of digestibility, but not of maturity or interaction maturity $\times$ methodology. The in vivo digestibility $(52.9 \%)$ was not different from the $24-\mathrm{h}$ in situ degradability $(55.6 \%)$ with numerical values in the range of the effective degradability. The in vitro digestibility (61.6\%) was not different from the 48-h in situ degradability (61.9\%), being both estimates higher than the in vivo digestibility. The 24-h in situ degradability was a closer estimator of the in vivo digestibility and the 48-h in situ degradability and the in vitro digestibility overestimated the in vivo parameter by $15-20 \%$.
\end{abstract}

Keywords: corn silage, in situ, in vitro and in vivo digestibility, ruminal kinetics

\section{RESUMO}

A degradabilidade in situ da matéria seca (MS) de silagens de milho em dois estados de maturidade (grão leitoso e meia linha de leite), de conhecida digestibilidade in vivo $e$ in vitro, foi determinada com o propósito principal de comparar valores de digestibilidade com a degradabilidade no rúmen após 24 e $48 \mathrm{~h}$ de incubação. Também foi analisada a cinética da digestão no rúmen, pelo modelo exponencial de McDonald, e foi calculada a degradabilidade efetiva, assumindo uma taxa de passagem de 4\%/h. Dados de digestibilidade in vivo, in vitro e de degradabilidade in situ a 24 e $48 \mathrm{~h}$ foram analisados com um modelo linear que incluiu o efeito do estado de maturação e metodologia de avaliação. Houve efeito significativo $(P<0,05)$ da metodologia na estimação da digestibilidade, mas não foi encontrado efeito da maturação ou da interação maturação $\times$ metodologia. A digestibilidade in vivo $(52,9 \%)$ não foi diferente da degradabilidade in situ a $24 \mathrm{~h}(55,6 \%)$, e apresentou valores numéricos na amplitude dos valores da degradabilidade efetiva. A digestibilidade in vitro $(61,6 \%)$ não foi diferente da degradabilidade in situ a $48 \mathrm{~h}(61,9 \%)$, e ambas as alternativas foram maiores do que a digestilidade in vivo. A degradabilidade in situ a 24 h de incubação é um bom preditor da digestibilidade in vivo da silagem de milho. Este parâmetro

Recebido para publicação em 19 de agosto de 2003

Recebido para publicação, após modificações, em 21 de setembro de 2004

*Corresponding autor (autor para correspondência)

E-mail: odimarco@balcarce.inta.gov.ar 
foi superestimado em $15-20 \%$ pela digestibilidade in vitro e pela degradabilidade in situ a $48 \mathrm{~h}$ de incubação.

Palavras-chave: silagem de milho, digestibilidade in situ, in vitro $e$ in vivo, cinética ruminal

\section{INTRODUCTION}

Whole corn plant silage is a complex feedstuff consisting of a mixture of grain and finely chopped forage, being both plant components of different nutritional value for the animal. While grains are highly digested (Andrae et al., 2001) the green part of the plant (stover) seems to be of limited digestibility. Leaf and stem tissues are hard to digest because of the complex structure of their cell walls (Buxton and Redfearn, 1997). Then, since silage particles remain less than $24 \mathrm{~h}$ in the rumen (Arieli et al., 1998; Satter et al., 1999), a great proportion of the stover particles will be expected to escape digestion. Consequently, the more resistant particles will end up in feces with the consequent depression of the stover and the whole corn plant silage in vivo digestibility (Morrison et al., 1998). For this reason diets based on corn silage were identified as having the most severe over-estimation of energy content by laboratory procedures (Siciliano-Jones and St. Pierre, 1997).

It is well known that the in vitro technique (Tilley and Terry, 1963) is accepted as the most appropriate and utilized lab methodology to estimate the digestibility of feedstuffs for ruminants (Fahey Jr. and Hussein, 1999). So, it is not surprising that the most available information on corn plant, corn stover and corn silage quality has been obtained with this methodology. However, it has to be considered that in this procedure samples are incubated in the test tube for a period of time of $48 \mathrm{~h}$, which is longer than the retention time that feed silage particles are exposed in vivo to microbial attack $(<24 \mathrm{~h})$. Siciliano-Jones and St. Pierre (1997) pointed out that this technique has shown a consistent overestimation of the in vivo digestibility of corn silages, being such over-estimation of approximately 15\% (Nomdedeu and Di Marco, 2001; Di Marco et al., 2002). These findings suggest that the in vitro digestibility could have severe limitations to estimate the in vivo digestibility in those situations in which the ingested material is suspected or known to be retained in the rumen for a time period shorter than the incubation one (48h). To avoid such over-estimation, a silage working team has recently proposed to estimate corn silage digestibility through the in situ ruminal disappearance at $24 \mathrm{~h}$ of incubation, procedure that has been termed in situ digestibility (Results..., 2001).

In situ data not only are useful for a more precise evaluation of silage energy concentration (Siciliano-Jones and St. Pierre, 1997) but also to quantify rates and pools being degraded in the rumen (Adesogan et al., 2000). In this sense, results obtained with this technique revealed that the soluble fraction of corn silage is, at least, as an important source of degradable substrates as the insoluble degradable one (Arieli et al., 1998). This kind of information, which can not be obtained by the in vitro procedure, may help to progress in the understanding of factors affecting silage digestion.

The objective of this study was to compare the in vivo digestibility of two corn silages at different maturity stages with the in vitro digestibility and the in situ degradability at 24 and $48 \mathrm{~h}$ of ruminal incubation, and to describe their ruminal digestion kinetics.

\section{MATERIALS AND METHODS}

An experiment was carried out in Balcarce, Buenos Aires province, Argentina $\left(37^{\circ} 45^{\prime} \mathrm{S}\right.$, $58^{\circ} 18^{\prime} \mathrm{W}$, altitude $130 \mathrm{~m}$ ), to complement a previous study, in which the effect of crop maturity on in vivo and in vitro DM digestibility was determined (Nomdedeu and Di Marco, 2001). Samples of two corn silages from a crop ${ }^{1}$ harvested in milk grain (R3) and half milk line (R5), according to the phenological scale of Ritchie et al. (1996), were incubated in two Holstein cows (440 and $450 \mathrm{~kg}$ body weight) with ruminal fistula. Animals were fed to maintenance body weight with a medium quality lucerne hay twice a day, at 9:00 (33\%) and 16:00h (67\%) in

${ }^{1}$ Suco, Novartis Seed Company 
individual outdoor corrals for a period of 10 days of adaptation previous to the incubation period. Two ground ( $2 \mathrm{~mm})$ samples $(5 \mathrm{~g} \mathrm{DM})$ per animal were incubated in the rumen for $0,4,9,15,24$, 48, 72 and 96h (Mehrez and Ørskov, 1977). Samples were placed in dacron bags $(10 \times 20 \mathrm{~cm}$, $50 \mu \mathrm{m}$ pore size) and previous to incubation they were hydrated for 5 minutes $\left(37^{\circ} \mathrm{C}\right)$. Four additional bags per animal at 24 and $48 \mathrm{~h}$ were used $(n=12)$. The $0-h$ corresponded to a ruminal incubation of 5 minutes to estimate the soluble fraction. After extraction, bags were rinsed thoroughly with cold tap water until the rinse water was clear. Then, they were dried until constant weight and weighed. Rumen liquor samples were taken by hand at $0,2.5,5$ and $8 \mathrm{~h}$ after feeding during two consecutive days and ruminal $\mathrm{pH}$ and ammonia nitrogen $\left(\mathrm{NH}_{3}-\mathrm{N}\right)$ concentration were determined.

The analysis of ruminal DM degradation kinetics was carried out following two successive steps. In the first one, the lag-time was estimated using the model described by McDonald (1981). Then, data of DM degradation beyond the lag-time were further adjusted to the model:

$\mathrm{P}=\mathrm{a}+\mathrm{b}\left(1-\mathrm{e}^{-\mathrm{ct}}\right)$, where

$\mathrm{P}=$ fraction degraded in the time $\mathrm{t}, \mathrm{a}=$ soluble fraction, $b=$ degradable fraction, $c=$ fractional degradation rate and $\mathrm{t}=$ incubation time.

Finally, the effective degradability (ED) was estimated assuming a passage rate $(\mathrm{kp})$ of $4 \% / \mathrm{h}$, as follows:

$\mathrm{ED}=\mathrm{a}^{\prime}+\left(\mathrm{b}^{\prime} \mathrm{c}\right) /(\mathrm{c}+\mathrm{kp})$, where

$a^{\prime}=$ observed degradability at time $0, b^{\prime}=a+b-a^{\prime}$
Digestibility and in situ degradability data were analyzed with a linear model including the fixed effects of maturity stage and methodology of evaluation. Dunnett test was used for the comparison between the in vivo digestibility and the other methodologies. The parameters of the McDonald (1981) model were estimated by the Marquart method and were compared by Tukey test considering each animal as a block. The analysis of data was carried out using the SAS (User's... 1996) package.

\section{RESULTS AND DISCUSSION}

As shown in Table 1, the in vivo DM digestibility $(52.9 \%)$ was not different $(\mathrm{P}>0.05)$ from the ruminal DM degradability at $24 \mathrm{~h}(55.6 \%)$ in agreement with Siciliano-Jones and St. Pierre (1997). However, it was lower $(\mathrm{P}<0.05)$ than the ruminal DM degradability at $48 \mathrm{~h}$ of incubation $(61.9 \%)$ and than the in vitro DM digestibility $(61.6 \%)$. In other words, these procedures overestimated the in vivo digestibility by approximately $15 \%$. It is important to note that both silages differed in DM (26 vs. 32\%), starch (13 vs. 28\%) and neutral detergent fiber contents (55 vs. 41\%), in accordance with their respective stages of maturity. However, no effects of maturity and interaction maturity $\times$ methodology on digestibility were observed (data not shown). Di Marco et al. (2002) reported that whole corn plant silage digestibility was not affected by maturity because the consequent depression in silage fiber digestibility was counteracted by an increase in starch content.

Table 1. Digestibility and ruminal degradability of DM of corn silage from a crop in two maturity stages

\begin{tabular}{lccccc}
\hline Methodology & $\mathrm{n}$ & Stage R3 & Stage R5 & Mean & EEM \\
\hline In vivo digestibility (\%) & 9 & $52.5 \pm 0.87$ & $53.5 \pm 0.64$ & $52.9 \mathrm{a}$ & 0.89 \\
In vitro digestibility (\%) & 10 & $60.1 \pm 0.33$ & $63.1 \pm 0.34$ & $61.6 \mathrm{~b}$ & 0.84 \\
24-h degradability (\%) & 12 & $54.4 \pm 1.49$ & $56.5 \pm 1.19$ & $55.6 \mathrm{a}$ & 0.79 \\
48-h degradability (\%) & 12 & $60.9 \pm 1.42$ & $62.8 \pm 1.38$ & $61.9 \mathrm{~b}$ & 0.74 \\
\hline
\end{tabular}

Effect of maturity and interaction maturity $\mathrm{x}$ methodology was not significant $(\mathrm{p}>0.05)$.

$\mathrm{n}=$ number of data for each stage of maturity.

Values followed by different letters indicate significant differences by test of Dunnett $(\mathrm{P}<0.05)$.

$\mathrm{EEM}=$ standard error of the mean.

The over-estimation of the in vivo digestibility by the in vitro technique or by the 48 -h in situ incubation suggests that a 48-h incubation period, used in both cases, might have exceed the time that the silage was retained in the rumen for in vivo digestion. Data of Arieli et al. (1998), Satter et al. (1999) and Kuehn et al. (1999) suggested that in high producing ruminants the ruminal retention time of corn silage might not be longer than $24 \mathrm{~h}$, which helps to explain the 
close similarity between values of in vivo DM digestibility and in situ degradability at $24 \mathrm{~h}$. Andrae et al. (2001) also reported data of 24-h in situ DM degradation (52\%) in range with the in vivo digestibility $(55 \%)$ of corn silage. On the other hand, values of 48-h in situ degradability or 48-h in vitro digestibility show that degradation of corn silage samples were similar in the rumen than in the test tube, in spite that conditions of fermentation in both cases might have been quite different (Adesogan et al., 2000).

It was found that maturity did not affect $(\mathrm{P}>0.05)$ the McDonald (1981) model parameters. The soluble fraction (a) was in average $32.3 \%$, the degradable fraction (b) $42.2 \%$ and the fractional degradation rate (c) $4.45 \% / \mathrm{h}$, with a lag time (L) period of $7.3 \mathrm{~h}$ (Table 2 ). The numerical valued of the estimated average effective DM degradability $(\mathrm{ED}=52.9 \%)$ was in range with the in vivo digestibility, suggesting that the passage rate $(\mathrm{kp})$ assumed in its estimation $(4 \% / \mathrm{h})$ might have been close to that in vivo. In fact, Kuehn et al. (1999) reported rate of passages between 4.0 to $5.5 \% / \mathrm{h}$ in high producing dairy cattle fed diets based on corn silage. In other words, coincidence among values of in vivo digestibility, 24-h-degradability and $\mathrm{ED}$ at a $\mathrm{kp}=4 \% / \mathrm{h}$ is indirectly indicating that particles of silage might not be retained in the rumen for digestion more than $24 \mathrm{~h}$. On the other hand, it is important to note that approximately $60 \%$ of the effective degradability is explained by the contribution of the soluble fraction (Table 2 ), which is in agreement with data reported by Arieli et al. (1998). Data indicated that the insoluble but degradable fraction was less important that the soluble one as a source of degradable substrates.

Table 2. Parameters of ruminal digestion kinetic and effective degradability (ED, $\mathrm{kp}=4 \% / \mathrm{h})$ of corn silages from a crop in two maturity stages

\begin{tabular}{lccc}
\hline Parameters & Stage R3 & Stage R5 & EEM \\
\hline Soluble fraction (a, \%) & 32.1 & 32.5 & 0.61 \\
Degradable fraction (b, \%) & 43.4 & 40.9 & 0.67 \\
Fractional degradation rate (c, \%/h) & 3.69 & 5.20 & 0.17 \\
Lag time (L, h) & 7.7 & 6.9 & 1.12 \\
$\mathrm{R}^{2}$ & 0.92 & 0.91 & \\
ED (\%) & 51.5 & 54.3 & 0.88 \\
\hline
\end{tabular}

Differences between maturity stage were not significant, test Tukey $(\mathrm{P}>0.05)$.

$\mathrm{EEM}=$ standard error of the mean

The in vivo DM digestibility of silages was in average $52.9 \%$ (Table 1 ), then if the gross energy is $4.4 \mathrm{Mcal} / \mathrm{kg} \mathrm{DM}$ and the losses for methane and urine are $18 \%$ of the digestible energy (Energy..., 1993), the concentration of metabolizable energy (ME) should be of $1.9 \mathrm{Mcal} / \mathrm{kg} \mathrm{DM}$. The same estimation from the 24-h in situ degradability is $2.0 \mathrm{Mcal} \mathrm{ME} / \mathrm{kg} \mathrm{DM}$. and from the in vitro digestibility $2.2 \mathrm{Mcal}$ $\mathrm{ME} / \mathrm{kg} \mathrm{DM}$, which clearly shows that in vitro data over-estimates the silage energy value, as pointed out by Siciliano-Jones and St. Pierre (1997).

Ruminal degradability was measured in a favorable environment for cellulolytic activity with an average ruminal $\mathrm{pH}$ of $6.73 \pm 0.21$ and an average $\quad \mathrm{N}^{-\mathrm{NH}_{3}}$ concentration of $17.6 \pm 4.73 \mathrm{mg} / 100 \mathrm{ml}$ (Satter and Slytter, 1974; Grant and Mertens, 1992). In spite of it, the DM degraded in $24 \mathrm{~h}$ was in average only $55.6 \%$ (Table 1). This low degradability value $(55.6 \%)$ is the result of the degradation of soluble carbohydrates, starch and part of the fiber fraction. Since soluble carbohydrates are completely degraded in the rumen and the starch is of high ruminal digestion (Owens et al., 1986; Johnson et al., 1999; Cammell et al., 2000), it is evident that the fibrous portion of the stover fractions (stalks, leaves, husks and cobs) might have been poorly degraded in 24 . In fact, as previously pointed out, $60 \%$ of the DE was accounted by the contribution of the soluble fraction. Although that in the area in which this experiment was carried out, this fraction will be expected to be depressed. In fact, Uhart and Andrade (1991) reported remobilization of assimilates from stalk to ears during kernel filling due to insufficient sunlight radiation. This should reduce the stalk soluble fraction, which 
might depress stalk degradability and, thus, the quality of the stover. The eventual effects of hybrids, agronomic practices (like irrigation, plant density or sowing date) and climate, upon stover degradability remain to be investigated, to understand the proper combination of factors that maximize grain yield and stover quality.

\section{CONCLUSIONS}

Corn silage in vivo DM digestibility was estimated satisfactorily by the in situ DM degradability at $24 \mathrm{~h}$ of ruminal incubation and by the effective degradability at a $\mathrm{kp}$ of $4 \% / \mathrm{h}$. The soluble fraction explained the main proportion of corn silage degraded in situ in 24$\mathrm{h}$. The in vivo DM digestibility was overestimated by the in vitro digestibility and by an in situ incubation of $48 \mathrm{~h}$ by $15-20 \%$, which indicates that both procedures over-predict silage energy concentration. However, digestibility estimated by any methodology was not affected $(\mathrm{P}>0.05)$ by the stage of maturity.

\section{ACKNOWLEDGEMENTS}

This work is part of the project 15/A106 "Evaluation of quality of plant and silage of maize", which is supported by the National University of Mar del Plata (Argentina).

\section{REFERENCES}

ADESOGAN, A.T.; GIVENS, D.I.; OWENS, E. Measuring the chemical composition and nutritive value in forages. In: t'MANNETJE, L.; JONES, R.M. (Eds.). Field and laboratory methods for grassland and animal production research. CABI Publishing, 2000.

ANDRAE, J.G.; HUNT, C.W.; PRITCHARD, G.T. et al. Effect of hybrid, maturity, and mechanical processing of corn silage on intake and digestibility by beef cattle. J. Anim. Sci., v.79, p.2268-2275, 2001.

ARIELI, A.; MABJEESH, S.J.; SHABI, Z. et al. In situ assessment of degradability of organic matter in the rumen of the dairy cow. J. Dairy Sci., v.81, p.1985-1990, 1998.
BUXTON, D.; REDFEARN, D. Plant limitations to fiber digestion and utilization. In: ANNUAL RUMINANT NUTRITION CONFERENCE, 37., Washington, 1997.

CAMMELL, S.B.; SUTTON, J.D.; BEEVER, D.E. et al. The effect of crop maturity on the nutritional value of maize silage for lactating dairy cows. 1. Energy and nitrogen utilization. Anim. Sci., v.71, p.381-390, 2000.

DI MARCO, O.N.; AELLO, M.S.; NOMDEDEU, M. et al. Effect of maize crop maturity on silage chemical composition and digestibility (in vivo, in situ and in vitro). Anim. Feed Sci. Technol., v.99, p.37-43, 2002.

ENERGY and protein requirements of ruminants. Wallingford, UK: CAB International, 1993. 159p.

FAHEY Jr., G.C.; HUSSEIN, H.S. Forty years of forage quality research: Accomplishments and impact from an animal nutrition perspective. Crop Sci., v.39, p.4-12, 1999.

GRANT, R.J.; MERTENS, D.R. Influence of buffer $\mathrm{pH}$ and raw corn starch addition on in vitro fiber digestion kinetics. J. Dairy Sci., v.75, p.2762-2768, 1992.

JOHNSON, L.; HARRISON, J.H.; HUNT, C. et al. Nutritive value of corn silage as affected by maturity and mechanical processing: a contemporary review. J. Dairy Sci., v.82, p.2813-2825, 1999.

KUEHN, C.S.; LINN, J.G.; JOHNSON, D.G. et al. Effect of feeding silages from corn hybrids selected for leafiness or grain to lactating dairy cattle. J. Dairy Sci., v.82, p.2746-2746, 1999.

McDONALD, I. A revised model for the estimation of protein degradability in the rumen. J. Agric. Sci., v.96, p.251-252, 1981.

MEHREZ, A.; ØRSKOV, E.R. A study of the artifitial fibre bag technique for determining the digestibility of feeds in the rumen. J. Agric. Sci., v.88, p.645-650, 1977.

MORRISON, T.A.; JUNG, H.G.; BUXTON, D.R. et al. Cell-wall composition of maize internodes of varying maturity. Crop Sci., v.38, p.455-460, 1998.

NOMDEDEU, M.; DI MARCO, O.N. Digestibilidad in vivo e in vitro y composición química del silaje de maíz en tres estados de 
madurez. Av. Prod. Anim., v.26, p.119-127, 2001.

OWENS, F.N.; ZINN, R.A.; KIM, Y.K. Limits to starch digestion in the ruminant small intestine. J. Anim. Sci., v.63, p.1634-1648, 1986.

RESULTS of corn silage analysis working group. Summary meeting on July 26, 1998 in Denver, CO. USA. URL: <http.www.uwex.edu/ ces/forage/cornsilage.csweb2.htm>. Consult May 2001.

RITCHIE, S.; HANWAY, J.; BENSON, G. How a corn plant develops? Ames: Iowa State University of Science and Technology, 1996. (Spec. Rep., 48).

SATTER, L.D.; JUNG, H.G.; VAN VUUREN, A.M. et al. Challenges in the nutrition of high producing ruminants. In: JUNG, H.; FAHEY, G. (Eds.). Nutritional ecology of herbivores. INTERNATIONAL SYMPOSIUM ON THE
NUTRITION OF HERBIVORES, 5., 1999, Illinois. Proceedings ... Illinois: ASAS, 1999.

SATTER, L.D.; SLYTER, L.L. Effect of ammonia concentration on rumen microbial protein production in vitro. Br. J. Nutr., v.32, p.199-208, 1974.

SICILIANO-JONES, J.; ST. PIERRE, N. Using in situ data in ration formulation. TRI STATE NUTRITION CONFERENCE. New York: FARME Institute, 1997.

TILLEY, J. TERRY, R. A two stage technique for the in vitro digestion of forages crops. $J$. $B r$. Grassl. Soc., v.18, p.104-111, 1963.

UHART, S.A.; ANDRADE, F.H. Source-sink relationships in maize grown in a cool-temperate area. Agronomie, v.11, p.863-875, 1991.

USER'S guide: statistics. Cary, NC: SAS Institute, 1996. 